\title{
Impact of State Government Development Scheme for Economic Empowerment on Community Dwellers of Anambra State Nigeria
}

\author{
ANGELA NNEKA ABASILIM \\ Department of Business Administration, School of Management Technology, \\ Federal University of Technology, Akure, Ondo State, Nigeria.
}

\begin{abstract}
The study examined the impact of Anambra Government's Grassroots Development Scheme on economic empowerment of community dwellers especially the youths and women, in all the local governments of Anambra state, in Southeastern Nigeria. The purpose was to assess the major beneficiaries of the development scheme and determine the impact of the scheme on the common people especially the youth and the women. The work is anchored on community development theory which emphasizes holistic approach to development through participation of all tiers of government, from the federal administrative office to the regional and local governments to community dwellers at grassroots level. Primary data was used for the study. The questionnaire was used for collection of data. The number of respondents for the study is 975 . Descriptive and inferential statistics were used for data analysis. The result of the study showed that a lot of the common people benefitted from the grassroots development scheme of the Anambra state Government. The hypothesis stated was tested at 0.05 level of significance to determine if the development scheme was beneficial to community dwellers of Anambra State using one-sample Kolmogorov-Smirnov $Z$ test and it was rejected because the $p$ value was less than $0.05(Z=0.6 .913$, $p=0.00$ ). The research findings also showed that the development scheme of the Anambra state government had also impacted positively on the people of the state, especially the youth and the women. The statistical significance of this result was determined using Pearson Chi-square coefficient. The hypothesis was because the $p$ value was less than $0.05\left(X^{2}=887.779\right.$, $\mathrm{df}=125, p=0.00)$. The study, therefore, concludes that the first tier of the grassroots development scheme of government in Anambra state
\end{abstract}

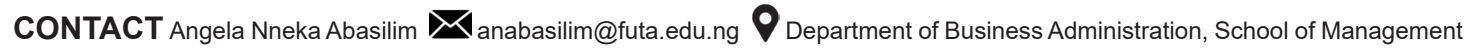
Technology, Federal University of Technology, Akure, Ondo State, Nigeria.

\section{(c) (i)}

(C) 2021 The Author(s). Published by Enviro Research Publishers.

This is an Open Access article licensed under a Creative Commons license: Attribution 4.0 International (CC-BY).

Doi: http://dx.doi.org/10.12944/JBSFM.02.01.13 
impacted positively on the life of the community dwellers of Anambra state, particularly the youth and women. The study recommends that more of such development scheme should be embarked upon by different tiers of government and other states in Nigeria should replicate same in their own states. This will be a way of boosting the economy, reducing unemployment, and diversifying economic activities.

\section{Introduction}

The Nigerian rural sector is very important for socio-economic growth of the country. It is noted as one of the vital sectors of the Nigerian economy. ${ }^{1}$ The authors noted that capital formation for the economy is majorly sourced from the rural sector of the country and the rural sector forms the principal market for domestic manufactures. Citing Abah, (2010) Ugwuanyi and Chukwuemeka observed that the bucolic communities participate in primary economic ventures that make up the basis for economic development in Nigeria. In a research conducted on poverty and sustainable socioeconomic development in Africa, Ighodalo, ${ }^{2}$ noted that most of the developing countries have one thing in common and that is a very high level of poverty that has reduced the ability of the people to transform themselves and environment in order to create enabling conditions necessary for continuous improvement in their human and physical conditions of life.

In Nigeria, poverty level has taken far wider dimensions which include personal income deficiency, dearth of food and security, unavailability of public services and structures, unhygienic atmosphere, low knowledge base, unsecured lives and properties, and poor governance and corruption. Nigerian polity is also characterized by a lack of participation in decision making process and in civil and socio-cultural life of the common people. This can be traced to absence of control over resources. ${ }^{3}$ The authors maintained that without putting social structures in place and ensuring participation of the people in resources control, citizens have inadequate contact with establishments, markets, employment prospects and civic amenities. This calls for pressing need for salient actions to be taken so as to combat poverty in the rural communities in Nigeria.

Bearing in mind the important contributions of the rural sector to the national economy and knowing that economic development, as well as fighting insecurity and corruption are among the major agendas of the present President Buhari administration in Nigeria, improving the development of the sector ought to be a prerogative to policy administrators. This will go further to enhance the capacity of the sector to yield an augmented input to the overall national growth and economic advancement. ${ }^{1}$ This is why Ighodalo ${ }^{2}$ suggested that the essence of every government is to ensure and bring to realization the political, social and economic interests of its people. One of the main aims of any modern government should be the promotion or pursuit of the welfare and wellbeing of their people especially at the grassroots. For this reason, policies and programmes that are targeted at the promotion and pursuit of welfare and wellbeing of the people are initiated and implemented.

Electricity supply has always been a problem in Nigeria, and Anambra State is not an exemption. The main source of water in Anambra State is through major rivers traversing the length of the State. Apart from electricity and water problems, Anambra State is also plagued by natural disasters like flooding and erosion menace. Chukwuemeka and Chukwujindu ${ }^{4}$ noted that due to many years of negligence and abandonment of infrastructure and corrupt leadership, added to natural disasters like flooding and erosion menace in some parts of the state, the changing human movement has constituted glitches for the state. Provision of physical and social infrastructures is not consummate with the growth in population. Environmental hygiene, erosion management, and delivery of social services are still problematic areas encountered in the state. Though road networks have improved in Anambra, but there are still unorganised building designs, poor sanitation, unrestrained street trading, garbage system that is not well managed, and chaotic transport systems, are still creating gridlock, noise pollution, and congestion. As such, Anambra state still has a lot of work to do in terms of 
meeting the demand and expectation of its citizenry. Infrastructural facilities such as good roads/networks of roads, supply of good and adequate water, access roads in rural areas and hinterlands, provision of infrastructure for basic education for the children and youths, healthcare services, transportation services, rural electrification programme and provision of information and communication technology (ICT) to the teaming and yearning people of Anambra state, though very much improved in recent years, are still inadequate. The authors observed that massive infrastructural requirements of the state have not been addressed; the mechanism for implementation and the resulting funding gap deteriorates the situation.

In the bid to address the development problems of the people at the grassroots, the Anambra State government embarked on development strategies like the Grassroots Development Scheme among others. The grassroots scheme was introduced in the middle of 2016. It is a community development scheme that has at its center the civic interest of the community dwellers. The community project which was billed to cover the 179 communities of the State is valued at about N7bn (about 18.4 million US dollars at $\$ 380$ in 2019). Divided into two phases with every community entitled to the sum of N20million (twenty million Naira, about fifty-three thousand US dollars) for each round of the programme. The first segment of the scheme was expected to end February/March 2017; with the second segment taking off almost immediately in March/April. The programme which was people based and specifically designed for communities is a well thought out venture in community development. ${ }^{5}$ Continuing, the Author noted that the present Anambra State grassroots scheme has reinstated communal creativity and involvement that are so critical to the successful outcome of the endeavour. It goes to say that the resolve of the peoples'needs, the choice of the project, as well as its position and contractor are the decisions to be made by the community. The communities are responsible for completion of the projects, providing a security network for supervision of construction and upkeep upon completion.

However according to Dollery and Wallis, ${ }^{6}$ responsible local leadership does not start and end with providing a range of local services but also about sustaining the life and freedom of residents, creating space for democratic involvement and community interchange, backing up market-led and ecologically maintainable local development, and enabling consequences that improve the quality of life of residents. It then becomes obvious that it is not just enough to lay claim to these development schemes but emphasis must be laid on, and questions must be asked on how far they are true, achievable and designed for the common people. This paper, therefore, is designed to investigate the outcome of the first phase of the Grassroots Development Scheme of government in Anambra State, Nigeria. As such, the following research questions were addressed;

- Who are the major beneficiaries of the development scheme?

- What is the impact of the scheme on the common people especially the youth and the women?

\section{Objectives of the Study}

The broad objective was to investigate the outcome of the first phase of the Grassroots Scheme of government for development in Anambra state. The specific objectives were to;

- Assess the major beneficiaries of the development scheme.

- Determine the impact of the scheme on the common people especially the youth and the women.

\section{Research Hypotheses}

The following hypotheses were tested;

- Nobody benefitted from the development scheme; and

- The scheme did not make any impact on the people.

\section{Literature Review}

\section{Community Development}

Community development is a strong instrument for eradicating poverty and achieving economic success at the grassroots level. The theory of community development incorporated by most economies presupposes a procedure through which bucolic poverty is reduced by relentless intensifications in the output and incomes of low-income workers and households. ${ }^{7}$ Community development theory 
identifies that upholding roles, structures and procedures which are performing well is vital and ensures a balanced respect for the effectiveness of tradition and social invention in a holistic approach that ensures that all facets of development are taken into account as a whole, working as a system for the benefit of all. ${ }^{8}$ The provision of social infrastructures is estimated in Nigeria as one of the most important requirements for community development. These social infrastructures include education, health, roads, electricity, and potable water, among others.

The realmeasure of any lasting, economic and social development programmes in Nigeria is majorly reliant on the extent to which it adds value to the welfare of the rural dwellers. This is based on the premise that bulk of the country's population and resources like land, natural and mineral resources are located in these areas. As much as the effect of rural poverty on development has been noted with its challenges in the global south and even in the global north, there are yet some level of arguments among policy makers on proper understanding and index for measuring rural development and by implication there is a lack of suitable policies and approaches for abolition of rural poverty. ${ }^{9}$ Gulet $^{10}$ identified three important aspect of community development to include, an increase in people's living standard that will reflect improvement in life styles, quality of life and well-being through access to medical services, education, safe drinking water; creating enabling environment for the development of people's self-actualization through the institution of communal organizations that sustain human dignity and esteem; increasing peoples'independence by broadening the range of the options available to them by adequate provision in varieties of human consumables. It, then, goes to say that any effort by the government to make life better for the people or to economically empower the people, must address these areas enumerated above. The government scheme must be able to raise the standard of living of the people; there must be easy access to health services, education, safe drinking water, and the ability to access micro credit for the people, especially the youth and women.

As such, for any meaningful headway to be made in community development, it must involve the participation of the people for whom it was meant. This is because, for Mamah, ${ }^{11}$ community developments pursue the empowerment of persons and groups by equipping them with the skills needed to drive changes in their peculiar environment. It includes changing the interdependency between the common man and people in position of authority, so that everyone can stake a part in the issues that affect their livelihoods. It seeks to empower individuals and groups in their own community. It is a development process of enabling a people to strengthen their capacities for self-empowerment aimed at achieving full social and economic potential.

\section{Participatory Community Development}

The lack of participation of recipients of development has been blamed for some of the disappointing performances of development efforts around the world. ${ }^{12,13}$ Participation implies the dynamic contribution of societies in need valuation, determination of priorities, preparation and implementation of projects. It also includes the involvement and input of potential beneficiaries to the realization of a project for their personal development. ${ }^{14}$

As Nwankwo ${ }^{15}$ observed, one of the basic problems confronting Nigeria's polity in recent time is lack of active involvement of the people in matters affecting them. Participation is a factor of manifold variables including involvement in policy-making process, implementation and execution of policies and decisions made, partaking in the benefits of made and implemented decisions and coordinating the entire process. Participation in community development ensures that community dwellers, irrespective of age or gender, partake in a course which allow them to direct their needs and to decide their own future with a view to ensure empowerment and sustainability. And the key factor in participation according to Ekpo and Olaniyi ${ }^{16}$ is the integration of homegrown knowledge into projects' decisionmaking process.

Participation is profitable for workable change as an active procedure by which individual recipients or groups impact the course and execution of development projects in order to advance their well-being in terms of development indices like income, personal growth, self-reliance and other cherished values. ${ }^{7}$ Cahn and Camper ${ }^{17}$ are of the view that when members of a community regardless of sex or age are given the chance to partake 
vigorously in the development of their community, we have participatory community development. Participatory community development according to them principally encourages communal members to take on the duty of resolving their own local issues through participation rather than through centralization of governance.
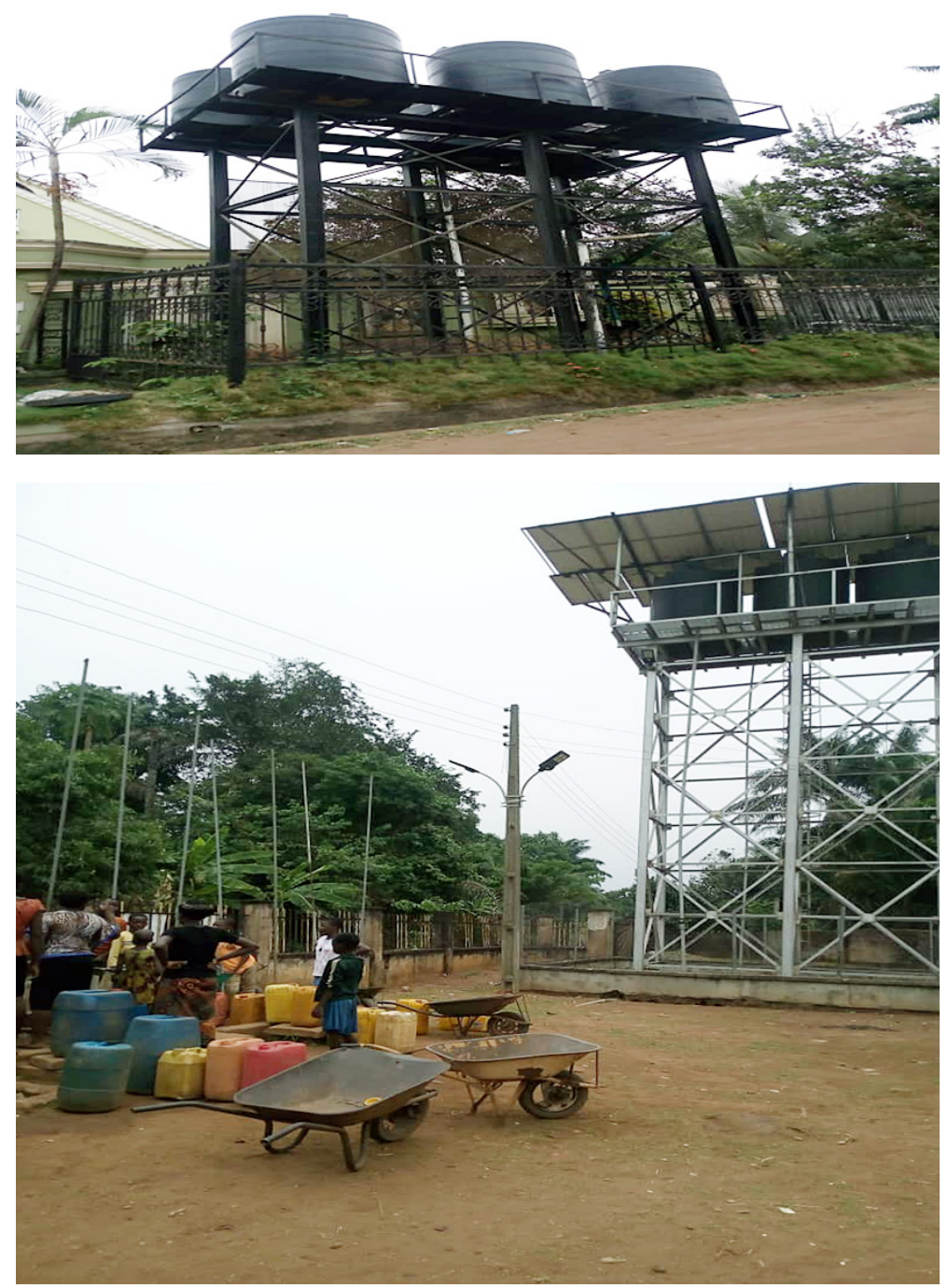

Fig. 1\& 2: Water Boreholes in some of the Communities of Anambra State

This is why the Christian Aids Nigeria, ${ }^{18}$ concluded that when a people are involved in the decision-making process, they cultivate a sense of proprietorship to the venture at hand. The sense of local rights that develop from the participatory process generate acceptability which when combined with integrity generate a strong social asset that allows every development project to be completed. As such, Mamah ${ }^{9}$ concludes that when a project is planned and implemented with the locals, there is always a better chance that it will be sustained and protected by these same people, thus it gains more standing. Involvement in community development begets commitment of both men and women. As observed by Gadi and Farkas, ${ }^{19}$ active involvement of both men and women in community projects is very essential. These authors claim that, it enables planners, researchers and community leaders as a whole to identify and formulate development programmes that will take into account the needs, 
attitudes and traditional knowledge of the local community. It is this participation that will drive the beneficiaries to become more committed to make the development projects successful and attainable.
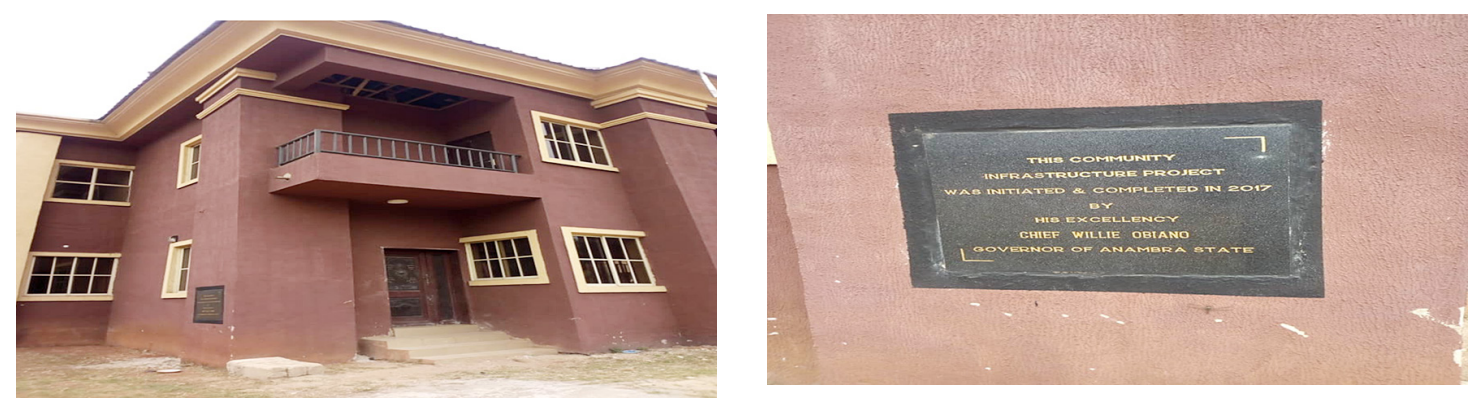

Fig. 3: Civic Centre in one of the Communities of Anambra State

\section{Materials and Methods}

Anambra State is located in Southeastern Nigeria (Figure 4). It is made up of 21 Local Government Areas/Councils and 179 towns/ communities. The 2006 Population Census put the population of Anambra state at $4,177,828$ and the population estimate for 2016 put it at $5,527,800 .^{20}$ Anambrarians, as the indigenes are addressed, are very hardworking and enterprising people, and most of the industrial activities of the state are owned and managed by the private sector, crisscrossing from agro-allied, automobile to manufacturing which are majorly situated in the Nnewi industrial town. Onitsha is the main commercial city, and Onitsha market is the biggest market in Anambra State and is acknowledged to be the biggest in West Africa.

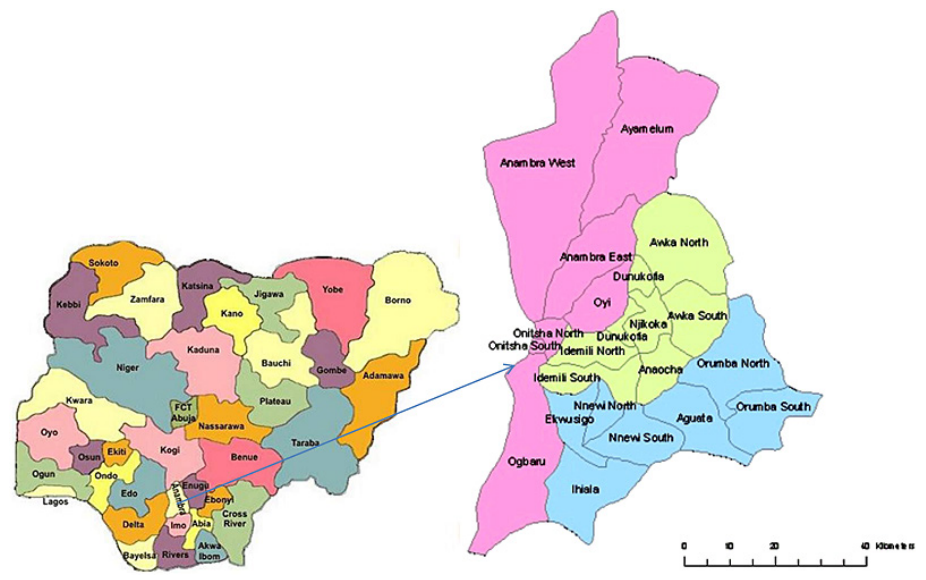

Fig. 4: Map of Nigeria and Map of Anambra State

Primary source of data collection was used for the study. The data were collected through administration of questionnaire using the Five-point Likert scale. Twenty-five statements of opinion were made to determine the major beneficiaries of the development scheme and the impact of the scheme on the common people especially the youth and the women. As such the respondents were asked to give their opinion on a Five-point Likert scale on the twenty-five statements made as plausible answers to the following questions:In your opinion who are the major beneficiaries of the government projects in your community? In what ways has the fund impacted on the lives of the youth and women? To what extent will you say that the development project donation has improved the lives of the people of the community, especially the youth and women? Thus, "To a very large extent" (5-points), "To a large extent" (4-points), "On an average extent" (3-points), "Not to a large extent" (2-points), or "Not at all" 
(1-point) of Likert Scale were used to elicit answers from the respondents.

The population is made up of all indigenes of Anambra State who dwell at home in the state. Anambra State is made up of 21 Local Government Areas/Councils which include Aguata, Awka North, Awka South, Anambra East, Anambra West, Anaocha, Ayamelum, Dunukofia, Ekwusigo, Idemili North, Idemili South, Ihiala,Njikoka, Nnewi North, Nnewi South, Ogbalu, Onitsha North, Onitsha South, Orumba North, Orumba South, and Oyi Local Government Areas.

Judgemental and convenient samplings were used to select 2 communities from each of these local government areas with exception of three local government areas which is a one town local government (Nnewi South, Onitsha North and Onitsha South). This gave a total coverage of 39 towns. The first and last towns according to alphabetical arrangement were purposively selected. This is done to remove author's bias from selection process. 25 respondents were chosen from each town, which gave 50 respondents from each local government area. The total number of respondents chosen for the study is 975 . This was done to ensure that respondents selected have the capability and knowledge to respond to the questions. Data collected were analysed using descriptive statistics of percentages, frequency distribution, and barcharts. Inferential statistics used are Chi-Square Tests, One-Sample Kolmogorov-Smirnov Test, and Cross tabulation.

\section{Decision Parameter}

The decision rule used throughout this analysis is to reject the null hypothesis (Ho) and accept the alternative $\mathrm{(Ha})$ if the resulting $p$-value is less than 0.05 level of significance $(p<0.05)$.

\section{Results and Discussion}

Distribution of Respondents by SocioDemographic and Economic Characteristics

Nine hundred and seventy-five (975) copies of questionnaire were distributed to selected respondents in this study. However, out of the 975 copies of questionnaire administered on the sampled population (respondents), 719 questionnaires (Seven hundred and nineteen) representing 73.7\% of the total questionnaires were found usable for statistical analysis (Table 1). The information on the table showed that $32.5 \%$ of the respondents are females while $67.5 \%$ are males. The majority of the respondents were within the age bracket of 31-50 years which represents $59.7 \%$. The information on the table also showed that most of the respondents were artisans and low-level civil servants (59.7\%).

\section{Major Beneficiaries of the Developmental Scheme}

The objective in this section examined the major beneficiaries of the grassroots development scheme of Anambra state. As such questions were asked to determine the major beneficiaries of development scheme. The major beneficiaries of the developmental scheme are displayed with bar-charts. The chart showed that the artisans were the major beneficiaries of the development scheme (Figure 5). The null hypothesis that nobody benefited from the development scheme was tested at 0.05 level of significance with one-sample KolmogorovSmirnov $Z$ test and it was rejected because the $p$ value was less than $0.05(Z=0.6 .913, p=0.00)$ (Table 2). The alternative was accepted which states that there are beneficiaries of the development scheme.

Impact of the Scheme on the Common People Especially the Youth and the Women

In this section, the objective sought to examine the impact of grassroots development scheme on the common people especially the youth and women. As such two sets of questions were asked to determine the impact of the scheme on the common people, especially the youth and women. All the questions were measured on five-point Likert scale from 'a very large extent' to 'not at all'. Cross tabulation and Chi square analysis were used for this purpose (Tables $3 \& 4$ ).

The statistical significance of this result was determined using Chi-square coefficient. The null hypothesis is that there is no significant impact of the scheme on the common people especially the youth and the women. This assumption was tested at 0.05 level of significance and it was rejected because the $p$ value was less than $0.05\left(X^{2}=887.779, d f=125\right.$, $p=0.00$ ). The alternative was accepted which states that there is a significant impact of the scheme on the common people especially the youth and the women. 
Table 1: Distribution of Respondents by Socio-

Demographic and Economic Characteristics

\begin{tabular}{|c|c|c|c|}
\hline \multicolumn{2}{|c|}{$\begin{array}{l}\text { Socio-Demographic and } \\
\text { Economic Characteristics }\end{array}$} & \multirow{2}{*}{$\begin{array}{c}\begin{array}{c}\text { Distribution } \\
\text { Frequency } \mathbf{n}=719\end{array} \\
234\end{array}$} & \multirow{2}{*}{$\begin{array}{c}\begin{array}{c}\text { Percentage } \\
(\%)=100\end{array} \\
32.5\end{array}$} \\
\hline Gender & Female & & \\
\hline & Male & 485 & 67.5 \\
\hline & Total & 719 & 100.0 \\
\hline \multirow[t]{7}{*}{ Age } & $21-30$ & 103 & 14.3 \\
\hline & $31-40$ & 210 & 29.2 \\
\hline & $41-50$ & 219 & 30.5 \\
\hline & $51-60$ & 51 & 7.1 \\
\hline & $61-70$ & 126 & 17.5 \\
\hline & 70\& Above & 10 & 1.4 \\
\hline & Total & 719 & 100.0 \\
\hline \multirow[t]{22}{*}{ LGA } & Aguata & 38 & 5.3 \\
\hline & Anambra East & 39 & 5.4 \\
\hline & Anambra West & 34 & 4.7 \\
\hline & Anaocha & 26 & 3.6 \\
\hline & Awka north & 40 & 5.6 \\
\hline & Awka south & 41 & 5.7 \\
\hline & Ayamelum & 27 & 3.8 \\
\hline & Dunukofia & 25 & 3.4 \\
\hline & Ekwusigo & 41 & 5.7 \\
\hline & Idemili north & 39 & 5.4 \\
\hline & Idemili south & 40 & 5.5 \\
\hline & Ihiala & 42 & 5.8 \\
\hline & Njikoka & 26 & 3.6 \\
\hline & Nnewi north & 11 & 1.5 \\
\hline & Nnewi South & 44 & 6.1 \\
\hline & Ogbaru & 44 & 6.1 \\
\hline & Onitsha north & 18 & 2.5 \\
\hline & Onitsha south & 19 & 2.6 \\
\hline & Orumba north & 44 & 6.1 \\
\hline & Orumba south & 41 & 5.7 \\
\hline & Oyi & 40 & 5.6 \\
\hline & Total & 719 & 100.0 \\
\hline \multirow[t]{8}{*}{ Occupation } & $\begin{array}{l}\text { Artisan (trader, carpenter, } \\
\text { bricklayer, cleaner, etc) }\end{array}$ & 250 & 34.8 \\
\hline & $\begin{array}{l}\text { Civil servant (teacher, govt. } \\
\text { worker, clerk, etc) }\end{array}$ & 179 & 24.9 \\
\hline & Farmer & 1 & 0.1 \\
\hline & Not employed yet & 65 & 9.0 \\
\hline & Religious leader & 4 & 0.6 \\
\hline & Student & 129 & 17.9 \\
\hline & Town union executive & 91 & 12.7 \\
\hline & Total & 719 & 100.0 \\
\hline
\end{tabular}




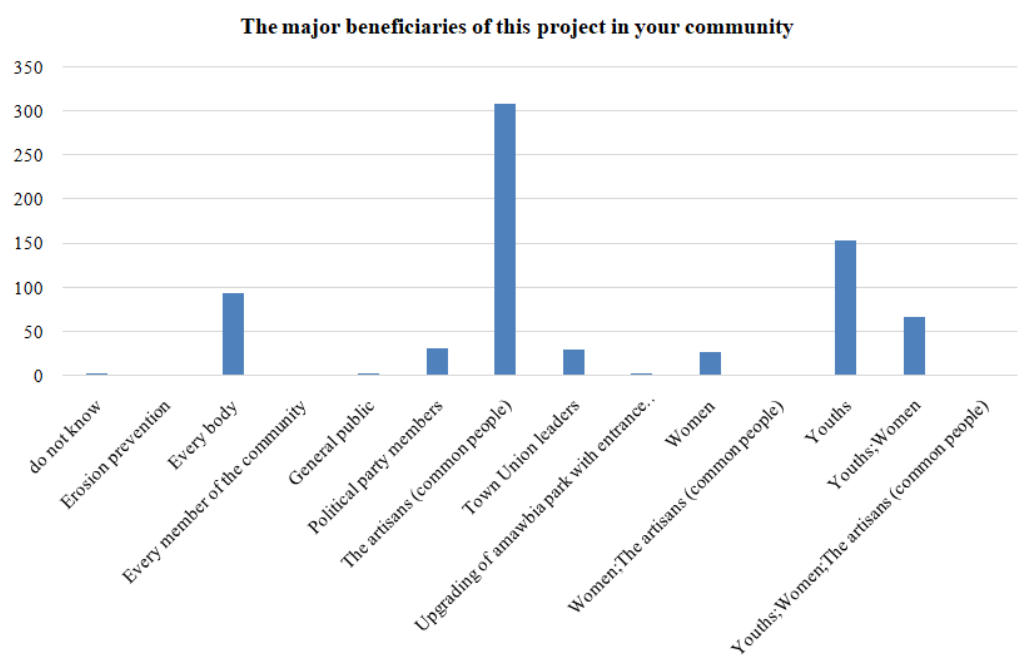

Fig. 5: Determine the Major Beneficiaries of the Developmental Scheme

Table 2: One-Sample Kolmogorov-Smirnov Test

In your opinion, who are the major beneficiaries of this project in your community?

\begin{tabular}{ll}
\hline $\mathrm{N}$ & 719 \\
Kolmogorov-Smirnov Z & 6.913 \\
$\mathrm{p}$ & .000 \\
\hline
\end{tabular}

Source: Field Survey 2018

Table 3: Cross tabulation of the Impact of the Scheme on the Common People Especially the Youth and the Women.

\begin{tabular}{|c|c|c|c|c|c|c|c|c|}
\hline & & \multicolumn{7}{|c|}{$\begin{array}{l}\text { To what extent will you say that the development project } \\
\text { donation has improved the lives of the people of } \\
\text { the community, especially the youth and women? }\end{array}$} \\
\hline & & $\begin{array}{l}\text { do not } \\
\text { know }\end{array}$ & $\begin{array}{l}\text { Not } \\
\text { at all }\end{array}$ & $\begin{array}{l}\text { Not to } \\
\text { a large } \\
\text { extent }\end{array}$ & $\begin{array}{l}\text { On an } \\
\text { average } \\
\text { extent }\end{array}$ & $\begin{array}{l}\text { To a } \\
\text { large } \\
\text { extent }\end{array}$ & $\begin{array}{l}\text { To a } \\
\text { very } \\
\text { large } \\
\text { extent }\end{array}$ & Total \\
\hline & & f & $f$ & $f$ & $f$ & $\mathbf{f}$ & $f$ & $f$ \\
\hline In what ways & No response & 2 & 0 & 1 & 0 & 0 & 1 & 4 \\
\hline has the fund & Access to education & 0 & 0 & 0 & 3 & 5 & 16 & 24 \\
\hline impacted on & Access to formal education & 0 & 0 & 0 & 0 & 0 & 1 & 1 \\
\hline the lives of & Access to healthcare services & 0 & 0 & 4 & 15 & 38 & 50 & 107 \\
\hline $\begin{array}{l}\text { the youth and } \\
\text { women? }\end{array}$ & $\begin{array}{l}\text { Access to healthcare services } \\
\text {; Prevention of erosion }\end{array}$ & 0 & 0 & 0 & 0 & 0 & 1 & 1 \\
\hline Through: & Access to quality education & 0 & 0 & 0 & 0 & 0 & 1 & 1 \\
\hline
\end{tabular}


ABASILIM, Journal of Business Strategy, Finance and Management, Vol. 02(1 \& 2) 131-143 (2021)

\begin{tabular}{|c|c|c|c|c|c|c|c|}
\hline Access to social meetings & 0 & 0 & 0 & 0 & 0 & 1 & 1 \\
\hline Access to transportation & 0 & 0 & 0 & 0 & 0 & 1 & 1 \\
\hline Access to transport & 0 & 0 & 0 & 0 & 0 & 2 & 2 \\
\hline Access to transportation & 0 & 0 & 0 & 0 & 0 & 4 & 4 \\
\hline Access to water transport & 0 & 0 & 0 & 0 & 1 & 2 & 3 \\
\hline Access to water transportation & 10 & 0 & 0 & 0 & 0 & 1 & 1 \\
\hline $\begin{array}{l}\text { Accommodation for social } \\
\text { gathering }\end{array}$ & 0 & 0 & 0 & 1 & 0 & 0 & 1 \\
\hline $\begin{array}{l}\text { Acquisition of skills from the } \\
\text { vocational centres }\end{array}$ & 0 & 0 & 1 & 3 & 18 & 14 & 36 \\
\hline $\begin{array}{l}\text { Acquisition of skills from the } \\
\text { vocational centres; Economic } \\
\text { empowerment through availabi } \\
\text { of necessary infrastructure( } w\end{array}$ & $\begin{array}{l}0 \\
\text { ility }\end{array}$ & 0 & 0 & 0 & 1 & 9 & 10 \\
\hline $\begin{array}{l}\text { Easy access to laboratories } \\
\text { for learning and training }\end{array}$ & 0 & 0 & 1 & 0 & 2 & 2 & 5 \\
\hline $\begin{array}{l}\text { Easy access to laboratories } \\
\text { for learning and training; } \\
\text { Access to healthcare services }\end{array}$ & 0 & 0 & 0 & 0 & 1 & 1 & 2 \\
\hline $\begin{array}{l}\text { Economic empowerment } \\
\text { through availability of } \\
\text { necessary infrastructure(water, } \\
\text { electricity, market stalls and } \\
\text { trading centre }\end{array}$ & 0 & 0 & 13 & 88 & 202 & 110 & 413 \\
\hline $\begin{array}{l}\text { Employment in the centres } \\
\text { established by the fund }\end{array}$ & 0 & 0 & 5 & 21 & 14 & 6 & 46 \\
\hline Erosion prevention & 0 & 0 & 0 & 1 & 9 & 2 & 12 \\
\hline $\begin{array}{l}\text { Hosting of Social and } \\
\text { political events }\end{array}$ & 0 & 0 & 4 & 4 & 3 & 3 & 14 \\
\hline Meetings & 0 & 0 & 1 & 1 & 5 & 2 & 9 \\
\hline Nothing & 0 & 2 & 2 & 0 & 0 & 0 & 4 \\
\hline Prevention of erosion & 0 & 0 & 1 & 3 & 7 & 4 & 15 \\
\hline Social and political gathering & 0 & 0 & 0 & 0 & 1 & 0 & 1 \\
\hline Social meetings & 0 & 0 & 0 & 0 & 0 & 1 & 1 \\
\hline Total & 2 & 2 & 33 & 140 & 307 & 235 & 719 \\
\hline
\end{tabular}

Source: Field Survey 2018

Table 4: Chi-Square Tests on the relationship between the extent to which the scheme improved the lives of the people and the impact the scheme made on the people from table 3

To what extent will you say that the development project donation has improved the lives of the people of the community, especially the youth and women.

\begin{tabular}{lll}
\hline In what ways has the fund & Chi-square & 887.779 \\
impacted on the lives of & df & 125 \\
the youth and women? & $\mathrm{p}$ & 0.000
\end{tabular}




\section{Discussion of Findings}

The result of the study showed that a lot of the common people benefitted from the grassroots development scheme of the Government of Anambra state. Of all the respondents, $43.1 \%$ agreed that the scheme benefitted the artisans (common people), $30.6 \%$ agreed that the youths benefitted from the development scheme, and $13.1 \%$ agreed that the women benefitted from the scheme. For instance, in most of the communities, schemes like provision of water boreholes, civic centers and fishing boats were embarked upon and concluded. These are things that artisans and women can use for micro and small-scale businesses. Adequate water supply for businesses like small scale garri manufacturing enterprises for the women and civic centers for skill acquisition and market stalls. It can therefore be seen that the grassroots development scheme of the government of Anambra state was beneficial to the people of the communities in Anambra state. This agrees with Nwachukwu and $\mathrm{Eze}^{7}$ who suggests that participation is productive for sustainable change as an active process by which recipients or individual groups impact the course and implementation of development projects in order to improve their wellbeing in terms of income, personal growth, selfreliance and other cherished values.

The research findings also showed that the development scheme of the Anambra state government has also impacted on the people of the state. $59.2 \%$ of the respondents agreed that the scheme provided economic empowerment through the provision of infra-structures like water boreholes, electrification schemes, trading centres/stalls, boats for riverine people for economic activities, etc. $15.4 \%$ agreed that the scheme provided the people easier access to health care facilities, and $6.4 \%$ of the respondents agreed that the scheme provided vocational centres for acquisition of skills for the people. This result is in agreement with Mamah $^{9}$ that community development seeks to empower individuals and groups of people by providing these groups with the skills they need to affect change in their own community.

\section{Conclusions}

The study, therefore, concludes that the first tier of the grassroots development scheme of Anambra state Government impacted positively on the life of the people of Anambra state, especially the youth and women. This conclusion validates the community development theory which emphasizes that holistic approach to development through participation of all tiers of government, from federal administrative agencies to state governments, to local municipalities and finally to the community dwellers at grassroots level will ensure all round development that is encompassing and inclusive.

\section{Recommendation}

The study recommends that the government and its agencies should come up with more of such schemes to help in empowering the people economically. This will be a way of boosting the economy, reducing unemployment, and diversifying economic activities. The scheme can also be replicated by all tiers of governments and other states governments in Nigeria.

\section{Acknowledgment}

I thank Dr. Emmanuel Olowokere and Dr. Tonia Okhankhuele (Federal University of Technology, Akure, Nigeria) for comments on the manuscript. I also extend my gratitude to John Abasilim for support towards the funding of this work as the work is self-funded.

\section{Funding}

The author(s) received no financial support for the research, authorship, and/or publication of this article.

\section{Conflict of Interest}

The authors do not have any conflict of interest.

\section{Reference}

1. Ugwuanyi, B. I., \& Chukwuemeka, E. O. (2013) "Enhancing Rural Development in Nigeria: Periscoping the Impediments and Exploring Imperative Measures". Kuwait
Chapter of Arabian Journal of Business and Management Review, 2(7), 91-101

2. Ighodalo, A. (2012) "Poverty and Sustainable Socio-economic Development in Africa: the 
Nigeria Experience". European Scientific Journal, 8 (26), 51-65

3. Ajani, E. N, Mgbenka, R. N, \& Onah, O. (2015) "Empowerment of Youths in Rural Areas through Agricultural Development Programmes: Implications for Poverty Reduction in Nigeria". International Journal of Research in Agriculture and Forestry, 2 (2) $34-41$

4. Chukwuemeka, E.,\&Chukwujindu, E. C. (2013) "The Effect of Anambra Integrated Development Strategy (ANIDS) on Nigeria Sustainable Development: An Appraisal (2006-2011)" European Journal of Business and Social Science, 2 (9) 95-113

5. Afuba, I. Anambra's Innovative Community Development Scheme. Nigeria: The Sun News; 20/02/2017. Sunnewsonline.com. Accessed on 26/01/2018

6. Dollery, .B. E. \& Wallis J. L. The Political Economy of Local Government Leadership, Reform, and Market Failure. ISBN 9781 84064 4517. Cheltenham, UK. Northampton, MA, USA: Edward Elgar.

7. Nwachukwu, I. N. \& Eze C. I., (2007)“Impact of Selected Rural Development Programs on Poverty Alleviation in Ikwuano LGA Abia State, Nigeria". African Journal of Food, Agriculture, Nutrition and Development.Rural Outreach Program, 7 (5)1-17

8. Zaw, Nicholus. T. 2018. "Community Development Theory: Basic introduction on how community development theories develop and work". Available at: www.academia. edu/2564568/community Development

9. Njoku, J. E. Governance, Management and Partnership Imperatives for Sustainable Agricultural Research, Food Security, Poverty Alleviation and Rural Development in Nigeria. Paper presented at National Workshop on Agriculture and Rural Development; May $22^{\text {nd }}-26^{\text {th }}$ 2000; NRCRI Umudike Abia State.

10. Gulet, (1971) "Women and Community Development: Historical Survey. In Mamah, C.I.(2011). Participation of Women in Community Development in Nigeria: a Case Study of Igbo Eze South Local Government Area, Enugu State. A project work submitted to the Department of Public Administration and Local Government, University of Nigeria,
Nsukka.

11. Mamah, C.I. (2011). Participation of Women in Community Development in Nigeria: a CaseStudy of Igbo Eze South Local Government Area, Enugu State. A project work submitted tothe Department of Public Administration and Local Government, University of Nigeria, Nsukka.

12. Waisbord, S., 2001. Family Tree of Theories, Methodologies and Strategies in Development Communication. [Online] New York: The Rockefeller Foundation. Available at: $<w w w$. communication for social change.org/pdf/ familytree/pdf>.

13. Willis, K., 2011. Theories and Practices of Development. London: Routledge. Available through: University of Reading Library website http://www.reading.ac.uk/library .

14. Mansuri, G. \& Rao, V. Community-Based and Driven Development: A Critical Review. The World Bank Research Observer;2004.1- 40 ISSN: 1564-6971 https://elibrary.worldbank. org/doi/abs/10.1093/wbro//kh012 03/2004. Accessed on 26/01/2018

15. Nwankwo, B. O. The challenges of political education in contemporary Nigeria:Re-thinkingmission and re-planning strategies. http://www.resjournals.com/ ERJDecember2012. Retrieved 2018, February 16

16. Ekpo, A. H. \&Olaniyi O. (1995).Rural Development in Nigeria: Analysis of the Impact of the Directorate for Food, Roads and Rural Infrastructure (DFRRI) 198693 In: Rural Development in Nigeria: Concepts, Processes and Prospects. Enugu: Autocentury Publishers

17. Cahn, E. S., \& Camper J. (1968)"Community Participation in Community Development". Journal of Community Development L-700

18. Christian Aid Nigeria. Enhancing Community Participation and Government Responsiveness: Approaches to Achieving Community Development. Nigeria: Christian Aid Nigeria; 2017.

19. Gadi, Blessing D. and Farkas, Attila, (2016). Effect of Women Empowerment to Community Development and Sustainable Development in Nigeria: 'A Case Study of Ghauta Day Festival in Kaduna State'. Available at SSRN: 
https://ssrn.com/abstract=3163956 or http:// dx.doi.org/10.2139/ssrn.3163956

20. National Population Commission. Population and Housing Census of the Federal Republic of Nigeria, I; 2006. 